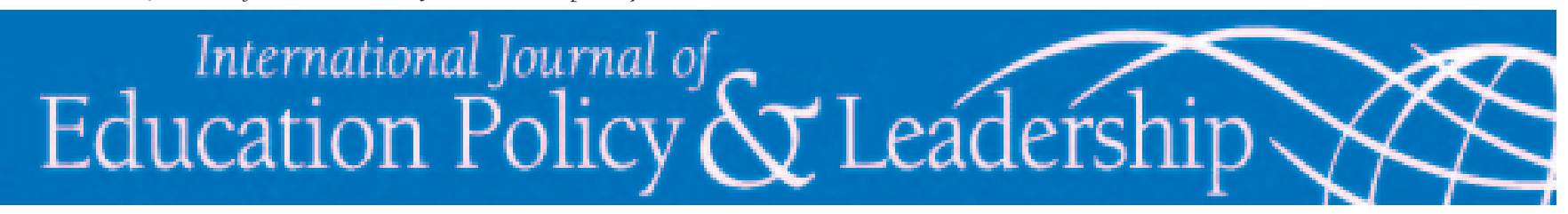

\title{
Salary and Ranking and Teacher Turnover: A Statewide Study
}

\author{
Cynthia MarTinez GARCIA \\ Corpus Christi Independent School District \\ JoHn R SLATE \\ Sam Houston State University \\ Carmen Tejeda Delgado \\ Texas A\&M University-Kingsville
}

\begin{abstract}
This study examined three years of data obtained from the Academic Excellence Indicator System of the State of Texas regarding teacher turnover rate and teacher salary. Across all public school districts, teacher salary was consistently negatively related to teacher turnover; that is, where salary was lower, turnover rate was higher When data were regrouped by highest- and poorest-paying school districts, teacher turnover rate was found to be twice as high in the poorest-paying school districts. Implications of these findings and suggestions for further research are discussed.
\end{abstract}

Garcia, C.M., Slate, J.R., Delgado, C.T. (2009). Salary and Ranking and Teacher Turnover: A Statewide Study. International Journal of Educatiuon Policy and Leadership, 4(7). Retrieved [DATE] from http://www.ijepl.org.

The pressing educational issue of teacher quality is driven by a growing recognition and an accumulation of research evidence of the critically important role that teachers play in student learning (Darling-Hammond, 2000; Darling-Hammond \& Sykes, 2003). A dramatic emphasis in recent years on the quality of teaching has been elevated by persuasive research demonstrating the relative importance of instruction for student achievement against other contextual factors (DarlingHammond, 2000; Darling-Hammond \& Sykes, 2003; Obama, 2005; Rice, 2003; Rowland \& Coble, 2005; Whitehurst, 2003). Unfortunately, many of the most highly qualified teachers do not teach in the schools where their skills are deeply needed. Teachers who have the least number of years of teaching experience and who, because of their inexperience, are among the least qualified to teach large numbers of at-risk students typically teach students at the poorest-achieving schools (Allen, Palaich, \& Anthes,1999; Darling-Hammond,
1998; Ingersoll, 1999, 2000, 2002; Nieto, 2003; Orfield \& Lee, 2005; Rowland \& Coble, 2005).

According to Ingersoll (2002), numerous research reports (e.g., Schools and Staffing Survey, Teacher Follow-up Survey, National Center for Education Statistics, Center for American Progress, U.S. Department of Education, and National Commission on Teaching and America's Future) have documented that the United States is at the peak of a severe teacher shortage. According to the National Center for Education Information (2007), the nation will require hiring about 2.2 million teachers in the next decade. A common response by policymakers to the probability of a teacher shortage is to increase the supply of teachers by implementing hiring initiatives. Though these recruitment efforts may be worthwhile, they will not solve the teacher staffing problems that some schools face.

Why is teacher turnover so high? The primary explanation most commonly offered is retirement. When 
available data are examined closely, however, it becomes evident that retiring from the profession is not a leading cause of teacher turnover (National Commission on Teaching and America's Future [NCTAF], 2003). "Why are so many beginning teachers, who enter the teaching profession because they have a real desire to make a positive impact in the lives of children, leaving their jobs?" asks the Alliance for Excellent Education [AEE] (2004, p. 1). Many researchers have noted that the primary factors are lack of professional support, poor working conditions, poor school leadership, and low salaries (Borman \& Dowling, 2008; NCTAF, 2003).

According to Buckley, Schneider, and Shang (2004), "school administrators and educational researchers have long known [that] hiring bright new teachers is only part of the problem-the attrition of both new and experienced teachers is as great a challenge for schools and school systems" (p. 1). Ingersoll \& Smith (2003) also assert that teacher attrition is a large part of the problem, and that attrition is particularly high among teachers during their first years of teaching. In Australia, England, Scotland, and Sweden, as well as in the United States, large numbers of experienced teachers leave before retirement (McKenzie \& Santiago, 2005). "Beginning teachers are more likely to be assigned low-performing students than their more experienced colleagues" (AEE, 2004, p 1). This difference in the types of students assigned to teachers is believed to make beginning teachers more vulnerable to leaving the teaching profession (AEE, 2004). Despite the many challenges of low-performing students, most beginning teachers are not provided professional support, feedback, or training on what it takes to help low-performing students succeed. The outcome is that new teachers are most at risk of leaving the teaching profession (AEE, 2004). Another important outcome is that teacher turnover differs most from other professions in the greater occurrence of turnover among experienced teachers, likely reflecting earlier retirement (Harris \& Adams, 2007). "We find some evidence that the relatively high ratio of pensionsto-salaries in teaching partially explains this behavior" (Harris \& Adams, 2007, p. 325). In a study of Australian teachers, across all age ranges, 33 percent of 10,019 respondents indicated that they intended to leave teaching within the next three years; 12.7 percent indicated that they intended to seek employment outside of education; and only 7 percent indicated that they intended to retire (Dempster, Sim, Beere, \& Logan, 2001).

In the 2003 NCTAF report, No Dream Denied: A Pledge to America's Children, the authors noted that the inability to support high-quality teaching in many schools is driven not by too few teachers entering the profession but by too many teachers leaving the teaching profession. Unfortunately, many schools have a difficult time retaining new teachers, especially at the highestneed schools. Ingersoll (2002) explained that recruiting more teachers will not solve the teacher crisis if large numbers of teachers then leave the profession within a very short period of time. In all schools, teachers are moving out of the profession; however, the rate of attrition is roughly 50 percent higher in poor schools than in wealthier ones (Ingersoll, 2003b).

Concern about the large number of new teachers who leave the work force is increasing, particularly considering that an estimated one-third of new teachers leave the profession after just three years, and almost half of new teachers leave the teaching profession within five years (NCTAF, 2003). According to the 2003 NCTAF report, "The real school staffing problem is teacher retention" (p. 8).

The teaching occupation represents about three to four percent of the entire civilian workforce in the United States (Ingersoll, 2003a, 2003b; Provasnik \& Dorfman, 2005). Roughly half of the teacher turnover in recent years resulted from teachers transferring to a different school, and the other half resulted from teachers leaving the profession for various reasons. The large number of teachers in the workforce, combined with high teacher turnover, indicates that there are large numbers of teachers entering and exiting schools each year (Ingersoll, 2003a). In the United States, many schools are becoming "revolving doors" because they are losing as many teachers as they hire annually (NCTAF, 2002, p. 6).

Teacher turnover has a negative impact on public education in three major areas: (a) student academic performance (NCTAF, 2003); (b) accountability (U.S. Department of Education, International Affairs Office, 2004); and (c) financial costs (Benner, 2000). The movement of teachers to better schools and the exit of teachers from the profession are costly phenomena, both for the students who lose the value of being taught by an experienced teacher and for the schools and districts that must recruit, hire, and train their replacements (Hammer \& Rohr, 1992; McKenzie \& Santiago, 2005; NCTAF, 2003). According to Ingersoll (2001b), "A central finding in the literature is that high levels of employee turnover are both cause and effect of ineffectiveness and low performance in organizations" (p. 505). "High turnover diminishes the sense of community, continuity, and coherence that are the hallmark of strong schools" 
(NCTAF, 2002, p. 9). In addition, teacher turnover is a challenging issue that affects school leaders' ability to sustain high student accountability ratings while constantly having to hire teacher replacements. "Research indicates that an increasing demand for teacher accountability and student achievement is at the forefront with the mandate of the No Child Left Behind Act (NCLB) of 2001" (Salinas \& Kritsonis, 2006, p. 1).

\section{Statement of the Problem}

Teacher turnover is a major problem for many schools and school districts (Ingersoll, 2003a; NCTAF, 2003). According to Ingersoll (2003a), two types of turnover that affect school staffing problems are teacher migration (i.e., movers - teachers who move to other schools) and teacher attrition (i.e., leavers - teachers who leave the teaching profession). From an administrative perspective, teacher migration and teacher attrition are both examples of teacher turnover that require schools or school districts to hire new teachers (Provasnik \& Dorfman, 2005). "The attrition of both new and experienced teachers is a great challenge for schools and school administrators throughout the United States, particularly in large urban districts" (Buckley, Schneider, \& Shang, 2004, p. 1).

Many researchers have documented that salary and poor working conditions influence teacher attrition (Joftus \& Maddox-Dolan, 2002; National Education Association, 2003). Between 1999-2000 and 2001-02, the teacher attrition rate increased from 8 percent to 10 percent in England due to the salary structure and working conditions (McKenzie \& Santiago, 2005). According to Dolton and van der Klaauw (1995), in the United Kingdom the teacher attrition rate was also related to poor salary. In an examination of the data from the Schools and Staffing Survey (SASS) and its supplement, the Teacher Follow-up Survey (TFS) conducted by the National Center for Education Statistics, Ingersoll (2001a, 2001b, 2004) reported that salary and student discipline were major factors in the high rates of teacher turnover. Ingersoll and Smith (2003) indicated that salary and working conditions rank as top reasons for teacher turnover. More recently, Borman and Dowling (2008), in a meta-analytic and narrative review of the research on teacher attrition and retention, concluded the following:

The evidence reviewed in this meta-analysis suggests that there are large numbers of characteristics of the environments in which teachers work that predict attrition. These characteristics include those noted prominently by Ingersoll (2001a, 2001b), including organizational features of school. However, our results indicate that they also include salaries and instructional resources provided to teachers, other organizational attributes of schools, and, also important, the characteristics of schools' student bodies. ( $p$. 398)

\section{Purpose of the Study}

The purpose of this study was to analyze school district and teacher characteristics that may be associated with teacher turnover. In essence, the research sought a better understanding of the factors related to the teacher turnover rates in many schools and school districts in Texas, to assist teachers, schools, and school district administrators in improving their teacher retention rates.

\section{Research Questions}

This study addressed the following research questions: What is the relationship between teacher turnover rate and average teacher salary in Texas? What is the difference between the highest- and the lowest-paying school districts in Texas in teacher turnover rate?

\section{Method}

\section{Participants}

Data from all public school districts in the State of Texas for the school years 2003-04, 2004-05, and 2005-06 were used in this study. The research questions were examined separately for data obtained from the State of Texas educational database for each of the three school years. Yearly, the Texas Education Agency collects a wide range of information on more than 1,200 school districts, almost 8,000 schools, more than 300,000 teachers, and about 4.5 million students through a statewide data management system known as Public Education Information Management System (PEIMS) (Texas Education Agency [TEA],n.d.).

\section{Instrumentation}

As noted previously, archival data were acquired from all public school districts in the State of Texas for the school years 2003-04, 2004-05, and 2005-06. The Texas Education Agency creates the Academic Excellence Indicator System (AEIS) (TEA, n.d) and other Webbased data reports using PEIMS-collected data. The AEIS 
database provides a broad range of information on the performance of students in each school and district in Texas yearly. Some of the performance indicators are Texas Assessment of Knowledge and Skills (TAKS), State Developed Alternative Assessment II (SDAA II), Reading Proficiency Test in English (RPTE) for limited-Englishproficient (LEP) students, attendance rates, and dropout rates. Each of these indicators was disaggregated by ethnicity, gender, special education, low-income status, and limited-proficiency status (TEA, n.d.). In addition, the database contains information on district schools and staff, finances, and student demographics. The collected data focused on teacher turnover as it related to teacher salary.

\section{Procedures}

Data were downloaded from the Texas Education Agency's Academic Excellence Indicator System Web site. For each school year included in the study, the researchers collected all of the school district files (1200+) for the State of Texas, as well as variables to be examined (teacher turnover rate and teacher salary) from the AEIS Web site, and saved each year's data as a Data $\{*$ dat $\}$ file. The data were then readily converted into SPSS and analyzed.

\section{Results}

The descriptive statistics for each of the variables and each of the school years in the study are listed in Table 1. For the 2005-06 academic year, teacher turnover rate

Table 1

Descriptive Statistics for Research Question Variables by Year

\begin{tabular}{lccc}
\hline Variable & $n$ & $M$ & $S D$ \\
\hline $2005-06$ & 1221 & 20.69 & 15.10 \\
Teacher Turnover Rate & 1227 & $\$ 37,362.29$ & 4155.63 \\
Teacher Salary & & & \\
2004-05 & 1222 & 22.14 & 14.39 \\
Teacher Turnover Rate & 1229 & $\$ 36,693.92$ & 4041.15 \\
Teacher Salary & & & \\
2003-04 & 1218 & 19.96 & 14.91 \\
Teacher Turnover Rate & 1227 & $\$ 36,323.77$ & 4209.05 \\
Teacher Salary & & & \\
\hline
\end{tabular}

was ( $M=20.69, S D=15.10)$, indicating that school districts in Texas had an average teacher turnover rate of 20 to 21 percent. The average teacher salary was $\$ 37,362.29$ ( $S D=4155.63$ ). In the 2004-05 academic year, the teacher turnover rate was $(\mathrm{M}=22.14, \mathrm{SD}=$ 14.39), indicating that the school districts had an average teacher turnover rate of 22 percent. The average teacher salary was $\$ 36,693.92$ ( $S D=4041.15)$. For the 2003-04 academic year, the teacher turnover rate was $(\mathrm{M}=19.96, \mathrm{SD}=14.91)$, indicating that school districts had an average teacher turnover rate of 20 percent. The average teacher salary was $\$ 36,323.77$ (SD $=4209.05$ ).

\section{Teacher Turnover Rate and Average Teacher Salary}

To determine whether a statistically significant relationship was present between teacher turnover rate and average teacher salary for all school districts in the State of Texas, a Pearson product-moment correlation coefficient was calculated for each of the three years. For the 2005-06 academic year, the finding was statistically significant, $\mathrm{r}(1221)=-.45, \mathrm{p}<.0001$, indicating the presence of a statistically significant negative relationship between teacher turnover rate and average teacher salary. Using Cohen's (1988) values, this r value reflects a moderate relationship. Squaring this $r$ value indicates a 20.16 percent overlap between teacher turnover rate and average teacher salary. That is, average teacher salary explained approximately 20 percent of the teacher turnover rate. For the 2004-05 academic year, the finding was again statistically significant, $r(1222)=-.44, p<$ .0001 , and was again a moderate effect size (Cohen, 1988). Squaring this $r$ value indicates that the two variables overlap by 19.71 percent. Finally, for the 2003-04 academic year, the finding was statistically significant, $r(1218)=-.48, p<$ .0001 , with a moderate effect size (Cohen, 1988). Squaring this $r$ value indicates that the two variables overlap by 22.94 percent. Across the three years of the AEIS database, findings were strikingly similar. That is, all three correlations had a magnitude ranging from .44 to -.48 ; reflected a mod- 
erate relationship between the variables of teacher turnover rate and average teacher salary; and accounted for approximately 20 percent of the variance.

Following this correlational analysis, the researchers performed a frequency distribution for the variable of teacher salary. On this basis, teacher salary was collapsed into a dichotomous variable: school districts in the lowest quartile for average teacher salary and school districts in the highest quartile for average teacher salary. Then, an analysis of variance (ANOVA) procedure was conducted to determine whether teacher turnover rate differed among the school districts with the highest average salary and school districts with the lowest average salary. As expected, for the 2005-06 school year, a statistically significant difference resulted, $\mathrm{F}(1,608)=166.42$, p < .0001 . The average teacher turnover rate was 15.17 percent $(\mathrm{SD}=9.43)$ for school districts in the top quartile of average teacher salary $(n=306)$, compared with an average teacher turnover rate of 31.84 percent $(S D=20.52)$ for school districts in the bottom quartile of average teacher salary $(n=304)$. Thus, the teacher turnover rate was slightly more than twice as high in the poorest-paying school districts as in the best-paying school districts. This difference resulted in an effect size of .52, considered by Cohen (1988) to be a large effect.

This same recoding procedure and statistical analysis were repeated for the 2004-05 school year. Again, a statistically significant difference resulted, $F(1,610)=$ $173.55, \mathrm{p}<.0001$. The average teacher turnover rate was 16.98 percent $(\mathrm{SD}=9.13)$ for school districts in the top quartile of average teacher salary $(n=306)$, compared with an average teacher turnover rate of 33.07 percent $(\mathrm{SD}=19.30)$ for school districts in the bottom quartile of average teacher salary $(n=304)$. The teacher turnover rate was almost twice as high in the poorest-paying school districts as in the best-paying school districts. This difference resulted in an effect size of .53, considered by Cohen (1988) to be a large effect.

This same recoding procedure and statistical analysis were again repeated for the 2003-04 school year. Again, a statistically significant difference resulted, $F(1,606)=$ 156.82, $\mathrm{p}<.0001$. The average teacher turnover rate was 15.08 percent $(S D=8.96)$ for school districts in the top quartile of average teacher salary $(n=307)$, compared with an average teacher turnover rate of 31.80 percent ( $\mathrm{SD}=21.58)$ for school districts in the bottom quartile of average teacher salary $(n=301)$. Again, the teacher turnover rate was more than twice as high in the poorest-paying school districts as in the best-paying school districts. This difference resulted in an effect size of .51, considered by Cohen (1988) to be a large effect.
In both the correlation analyses and the ANOVA analyses, teacher salary was clearly linked, at the large effect size level, with teacher turnover rate. These findings were consistent across the three years of statewide school district data analyzed.

\section{Discussion}

This study clearly links teacher salary and teacher turnover rate for Texas school districts. Where the average teacher salary was higher, a moderate tendency was present for the teacher turnover rate to decrease. These findings are congruent with Ingersoll's statement (2001a, $2001 b, 2004)$ that salary was a major factor related to high rates of teacher turnover. In addition, Scott (2004) has described average teacher salary as a factor related to teacher turnover in Texas public schools. Many other researchers have shown that salary influences teacher attrition at the national level (Joftus \& Maddox-Dolan, 2002; NEA, 2003) and at the international level (McKenzie \& Santiago, 2005; Dolton \& van der Klaauw, 1995). Thus, the findings from this study, based on three years of data for all school districts in the State of Texas, are congruent with findings at both the national and international levels.

The State Board of Educator Certification and Texas Education Agency's analysis of Texas teacher average base salaries and teacher turnover at campuses between 2002-03 and 2003-04 indicated that turnover was the highest where teacher pay was the lowest (Texas Comptroller, 2004). In 2004, depending upon the teacher certification, comparable jobs in Texas requiring the same skills paid from $\$ 4,546$ to $\$ 8,038$ per year more than teaching positions (Texas Comptroller, 2006). This finding may be interpreted to mean that, in 2004, switching to another occupation requiring essentially the same skills could earn a former teacher an average salary increase ranging from 9.9 to 19.0 percent (Texas Comptroller, 2006). Complex educational challenges of recruiting and retaining qualified teachers have focused attention on the competitiveness and career earning potential of salaries in education compared with salaries in the private sector (NEA, 2005a).

Researchers have documented that a lack of competitive compensation and benefits, along with poor working conditions, is the primary reason for high teacher turnover in Texas (Texas State Teachers Association, 2007). As mentioned previously, in Australia, England, Scotland, and Sweden, relatively high proportions of teachers leave teaching for reasons such as salary (McKenzie \& Santiago, 2005). According to Dolton and van der Klaauw (1995), teacher attrition rate in the 
United Kingdom is also related to poor salary. Marshall (2002) stated that teachers' salaries continue to rank far below the salaries of other professionals.

Recently, teachers in 41 states and the District of Columbia saw their spending ability shrink as a result of rising inflationary costs, and in three of these statesMaine, West Virginia, and Alabama-average teacher salaries dropped below the previous year's level (NEA, 2005c). Teacher salaries increased at a rate higher than inflation in only nine U.S. states (NEA, 2005c). Texas, the state whose data were analyzed in this study, ranked 32 nd in the nation for average teacher salary in 2003-04; the following year (2004-05), the state ranked 33rd (NEA, 2005b).

We must have qualified teachers in every classroom to give students a fair chance at success. For that to happen, legislatures (in this case the Texas legislature) must address the reasons teachers are leaving the profession (Texas State Teachers Association, 2007). According to the NEA's (2005b) update to the annual report titled Rankings and Estimates: Rankings of the States 2004 and Estimates of School Statistics 2005, inflation increased 3.1 percent over the previous year, but teacher salaries increased by only 2.3 percent. Low pay drives away too many of the best educators from the teaching profession (Texas Comptroller, 2004).

In 2007, in completing an 18-month study of the cost of teacher turnover in five school districts across the United States, the NCTAF examined the cost of recruiting, hiring, processing, and training teachers at both the school and district levels. As noted in the AEE (2005), "Many analysts believe that the price tag is even higher; hiring costs vary by district and sometimes include signing bonuses, subject matter stipends, and other recruiting costs specific to hard-to-staff schools" (p. 1). Other analysts believe that the expense of the loss in student achievement and teacher quality should also be included in the expense statement (AEE, 2005; Benner, 2000). The high rates of teacher turnover directly impact student achievement, teacher quality, and school/school district accountability and are a costly occurrence (NCTAF, 2003).

More research is certainly needed in this area. Studies that place a focus on urban, suburban, and rural schools and their relationship regarding teacher turnover rate would be informative. Finally, researchers are encouraged to use state educational databases. This study used the Academic Excellence Indicator System for the State of Texas, which has a wealth of data across many years, a database which these authors believe to be substantially underused.

\section{References}

Allen, M., Palaich, R., \& Anthes, C. (1999). Teacher recruitment, preparation, and retention for hard-to-staff schools. A Report of the August 29-30, 1999, Meeting in Chicago. Denver, CO: Education Commission of the States. Retrieved October 8, 2008,from

http://www.ecs.org/initiatives/geringer/chicago\%20h ard-to-staff\%20meeting\%20report.htm

Alliance for Excellent Education. (2004). Tapping the potential: Retaining and developing high-quality new teachers. Washington, DC: Author.

Alliance for Excellent Education. (2005, August). Teacher attrition: A costly loss to the nation and to the states (Issue Brief). Washington, DC: Author. Retrieved November 5, 2008, from http://www.all4ed.org/files/archive/publications/Teac herAttrition.pdf

Benner, A. D. (2000). The cost of teacher turnover. Austin, TX: Texas Center for Educational Research.

Borman, G. D., \& Dowling, N. M. (2008). Teacher attrition and retention: A meta-analytic and narrative review of the research. Review of Educational Research, 78(3), 367-409.

Buckley, J., Schneider, M., \& Shang, Y. (2004). The effects of school facility quality on teacher retention in urban school districts. Washington, DC: National Clearinghouse for Educational Facilities. Retrieved October 22, 2008, from http://www.edfacilities.org/pubs/teacherretention.pd f

Cohen, J. (1988). Statistical power analysis for the behavioral sciences (2nd ed.). New York: Wiley.

Darling-Hammond, L. (1998, September). How can we ensure a caring, competent, qualified teacher for every child? National Commission on Teaching \& America's Future. Paper presented at the American Federation of Teachers/National Education Association Joint Conference, Washington, DC. Retrieved October 22, 2008, from http://www.middleweb.com/TchRcrtLDH.html

Darling-Hammond, L. (2000). Teacher quality and student achievement. A Review of State Policy Evidence. Education Policy Analysis Archives, 8, 1. Retrieved October 8, 2008, from http://epaa.asu.edu/epaa/v8nl/ 
Darling-Hammond, L., \& Sykes, G. (2003). Wanted: A national teacher supply policy for education: The right way to meet the "highly qualified teacher" challenge. Education Policy Analysis Archives, 11, 33. Retrieved October 22, 2008, from http://epaa.asu.edu/epaa/v1ln33/

Dempster, N., Sim, C., Beere, D., \& Logan, L. (2001). Teachers in Australian schools: A report from the 1999 national survey (Executive Summary). Canberra: Australian College of Education.

Dolton, P. J., \& van der Klaauw, W. (1995). Leaving teaching in the UK: A duration analysis. Economic Journal, 105, 431-444.

Hammer, C. H., \& Rohr, C. L. (1992). Teacher attrition and migration (Issue Brief, NCES IB-2-92).

Washington, DC: National Center for Educational Statistics.

Harris, D. N., \& Adams, S. (2007). Understanding the level and causes of teacher turnover: A comparison with other professions. Economics of Education Review, 26, 325-337.

Ingersoll, R. M. (1999). The problem of underqualified teachers in American secondary schools.

Educational Researcher, 28(2), 26-37.

Ingersoll, R. M. (2000). Why do high-poverty schools have difficulty staffing their classrooms with qualified teachers? Renewing our Schools: Securing our future. A National Task Force on Public Education. A joint initiative of the Center for American Progress and the Institute for America's Future. Retrieved October 8, 2008, from http://www.americanprogress.org/kf/ingersoll-final.pdf

Ingersoll, R. M. (2001a). Teacher turnover, teacher shortages, and the organization of schools. Seattle, WA: University of Washington, Center for the Study of Teaching and Policy.

Ingersoll, R. M. (2001b). Teacher turnover and teacher shortages: An organizational analysis. American Educational Research Journal, 38(3), 499-534.

Ingersoll, R. M. (2002). Out-of-field teaching, educational inequality, and theorganization of schools: An exploration analysis. Seattle, WA: University of Washington, Center for the Study of Teaching and Policy.

Ingersoll, R. M. (2003a). Is there really a teacher shortage? Seattle, WA: University of Washington, Center for the Study of Teaching and Policy.

Ingersoll, R. M. (2003b). Out-of-field teaching and the limits of teacher policy. Seattle, WA: University of Washington, Center for the Study of Teaching and Policy.
Ingersoll, R. M. (2004, November). Why do high-poverty schools have difficulty staffing their classrooms with qualified teachers? Commissioned paper for the Center for American Progress. Washington, DC.

Ingersoll, R. M., \& Smith, T. M. (2003). The wrong solution to the teacher shortage. Educational Leadership, 60(8), 30-33.

Joftus, S., \& Maddox-Dolan, B. (2002). New teacher excellence: Retaining our best. Washington, DC. Alliance for Excellent Education. (ERIC Document Reproduction Service No. ED473235)

Marshall, I. (2002). A study of the factors contributing to the attrition rate of public school teachers in Texas. Unpublished doctoral dissertation, Texas A\&M University-Kingsville and Texas A\&M University-Corpus Christi.

McKenzie, P., \& Santiago, P. (2005). Attracting, developing, and retaining effective teachers: Teachers matter. Paris, France: Organisation for Economic CoOperation and Development.

National Center for Education Information. (2007). Overview of alternative routes to teacher certification. Washington, DC: National Center for Alternative Certification. Retrieved November 6, 2008, from http://www.teach-now.org/overview.html

National Commission on Teaching and America's Future. (2002). Unraveling the "teacher shortage" problem: Teacher retention is the key. Washington, DC: Author.

National Commission on Teaching and America's Future. (2003). No dream denied: A pledge to America's children. Washington, DC: Author.

National Commission on Teaching and America's Future. (2007). Cost of teacher turnover study. Washington, DC: Author. Retrieved November 6, 2008, from

http://www.nctaf.org/resources/demonstration_projects/t urnover/index.htm

National Education Association. (2003). Status of the American public school teacher 2000-2001. Washington, DC: Author. Retrieved October 14, 2008, from http://www.nea.org/edstats/images/status.pdf

National Education Association. (2005a). Rankings $E$ estimates: Rankings of the states 2004 and estimates of school statistics 2005. Washington, DC: Author. Retrieved October 8, 2008, from http://www.nea.org/edstats/images/05rankings.pdf 
National Education Association. (2005b). Rankings \& estimates update: A report of school statistics. Washington, DC: Author. Retrieved October 14, 2008, from http://www.nea.org/edstats/images/05rankingsupdate.pdf

National Education Association. (2005c). Inflation outpaces teacher salary growth in more than 40 states. Washington, DC: Author. Retrieved October 14, 2008, from http://www.nea.org/newsreleases/2005/nr051205.html

Nieto, S. M. (2003). What keeps teachers going? Educational Leadership, 60(8), 15-18.

Obama, B. (2005). Teaching our kids in a 21st century economy. Remarks as prepared for delivery at the Center for American Progress, Washington, DC. Retrieved October 14, 2008, from http://obama.senate.gov/speech/051025teaching_our_ki/

Orfield, G., \& Lee, C. (2005). Why segregation matters: Poverty and educational inequality. The Civil Rights Project. Cambridge, MA: Harvard University. (ERIC Document Reproduction Service No. ED 489186)

Provasnik, S., \& Dorfman, S. (2005). Mobility in the teacher workforce (NCES 2005-114). U.S. Department of Education, National Center for Educational Statistics. Washington, DC: U.S. Government Printing Office.

Rice, J. K. (2003). Teacher quality: Understanding the effectiveness of teacher attributes. Washington, DC: Economy Public Institute.

Rowland, C., \& Coble, C., (2005, November). Targeting teacher recruitment and retention policies for at-risk schools (Policy Issue No. 20). North Central Regional Educational Laboratory. (ERIC Document Reproduction Service No. ED 489524)

Salinas, R. A., \& Kritsonis, W. A. (2006). The national challenge of teacher quality and student achievement in public schools. National Journal for Publishing and Mentoring Doctoral Student Research, 1,1 .
Scott, R. D. (2004). Antecedents of teacher turnover: An empirical study of the Texas public school system. Dissertation Abstracts International, 65, (09).

Texas Comptroller. (2004). The cost of underpaying Texas teachers. Special report.

Retrieved October 14, 2008, from

http://www.window.state.tx.us/specialrpt/teachersalary04/

Texas Comptroller. (2006). The cost of underpaying Texas teachers, updated. Retrieved October 14, 2008, from http://www.window.state.tx.us/specialrpt/teachersalary06/

Texas Education Agency. (n.d.). Academic Excellence Indicator System. Retrieved

October 14, 2008, from http://www.tea.state.tx.us./perfreport/aeis/index.html

Texas Education Agency. (n.d.). Public Education Information Management System.

Retrieved October 14, 2008, from http://www.tea.state.tx.us/peims/index.html

Texas State Teachers Association. (2007). Making educational leadership a reality in Texas. Retrieved October 14, 2008, from http://www.tsta.org/legislative/update/07TSTALEG\%20BROCH-web.pdf

U.S. Department of Education, International Affairs Office. (2004). Attracting, developing, and retaining effective teachers. Washington, DC: Author.

Whitehurst, G. (2003). Research on teacher preparation and professional development. White House Conference on Preparing Tomorrow's Teachers. Washington, DC. Retrieved November 6, 2008, from http://www.ed.gov/admins/tchrqual/learn/preparingteachersconference/whitehurst.html

IJEPL is a joint publication of the Association for Supervision and Curriculum Development, the Faculty of Education at Simon Fraser University, and the College of Education and Human Development at George Mason University. By virtue of their appearance in this open access journal, articles are free to use, with proper attribution, in educational and other non-commercial settings 90 days after initial publication. Copyright for articles published in IJEPL is retained by the authors. More information is available on the IJEPL Web site: http://www.ijepl.org 